\title{
Behaviour Intention to Use dan Use Behaviour Mahasiswa dalam Menggunakan E-Learning dimasa Covid-19
}

\author{
Muhammad Ikhlash", Herjunda Faghfirka Tama* \\ *Politeknik Negeri Batam \\ Program Studi Akuntansi Manajerial \\ Jl. Ahmad Yani, Batam Kota, Batam 29461, Indonesia \\ Email: ikhlash@polibatam.ac.id
}

\begin{abstract}
Abstrak
Menanggapi Covid-19 yang dijadikan sebagai pandemik global, Politeknik Negeri Batam memutuskan proses pembelajaran melalui daring sehingga menyebabkan adanya peningkatan intensitas pada pengguna $e$-learning . Tujuan penelitian ini adalah untuk menguji secara empiris niat dan perilaku mahasiswa dalam menggunakan $e$ learning. Penelitian ini terbatas pada ruang lingkup untuk menguji secara empiris pengaruh performance expectancy, effort expectancy, social influence, work life quality, hedonic motivation terhadap behaviour intention to use, dan behaviour intention to use terhadap use behaviour mahasiswa dalam menggunakan e-learning. Penelitian ini dilakukan dengan memakai pendekatan kuantitatif. Responden dalam penelitian ini sebanyak 94 responden. Pengumpulan data dilakukan dengan menyebarkan kuisioner, kemudian di analisis menggunakan Smart PLS versi 3.0 untuk menguji instrumen dan hipotesis. Hasil penelitian membuktikan bahwa performance expectancy dan hedonic motivation berpengaruh positif terhadap behaviour intention to use, sedangkan effort expectancy, social influence, work life quality tidak berpengaruh. Variabel behaviour intention to use berpengaruh positif terhadap use behaviour.
\end{abstract}

Kata Kunci: Performance Expectancy, Effort Expectancy, Social Influence, Work-Life Quality, Hedonic Motivation, Behaviour Intention to Use, Use Behaviour.

\section{Abstract}

In response to Covid-19, which was used as a global pandemic, Politeknik Negeri Batan decided the online learning process, causing an increase in the intensity of e-learning users. This research aims to empirically test students' intentions and behaviour in the use of e-learning. This research is limited in scope to test empirically the effect of performance expectancy, effort expectancy, social influence, work-life quality, hedonic motivation on behaviour intention to use, and behaviour intention to use on student use behaviour in using e-learning. This research was conducted with a quantitative approach. Respondents in this study are 94 respondents. Data was collected by distributing questionnaires, then analyzed using Smart PLS version 3.0 to test instruments and hypotheses. The study results prove that performance expectancy and hedonic motivation positively affect behaviour intention to use, while effort expectancy, social influence, and work-life quality have no effect. The behavioural intention to use variables has a positive effect on use behaviour.

Keyword: Performance Expectancy, Effort Expectancy, Social Influence, Work-Life Quality, Hedonic Motivation, Behaviour Intention to Use, Use Behaviour.

\section{Pendahuluan}

Surat Edaran Nomor 3 tahun 2020 yang dikeluarkan oleh Kementerian Pendidikan dan Kebudayaan Republik Indonesia, menetapkan bahwa pembelajaran dilakukan sepenuhnya melalui fasilitas daring, sehingga memberikan dampak terhadap sistem pembelajaran di Indonesia yang mulanya dilakukan secara tatap muka kini sepenuhnya dialihkan dalam bentuk daring guna mencegah penyebaran virus Covid-19. Politeknik Negeri Batam melalui surat edaran Nomor: 289/PL29/III/2020 telah memutuskan untuk melaksanakan pembelajaran secara daring terhitung dari tanggal 16 maret 2020 guna menindaklanjuti kewaspadaan dan mencegah penyebaran virus COVID-19 di lingkungan kampus.

Munculnya "cyber teaching” atau e-learning ialah salah satu pilihan institusi untuk mendukung proses pembelajaran tidak terkecuali pada pendidikan vokasi di Indonesia di era pandemik saat ini. Menurut Rosenberg (2001) dengan Perkembangan teknologi dan komunikasi saat ini, menjadikan perubahan dalam proses pembelajaran dari ruang kelas kini bisa dilaksanakan kapan pun dan di mana pun, dari kertas berubah menjadi media online, dan dari fasilitas fisik beralih menjadi fasilitas jaringan. 
E-learning didefinisikan sebagai metode penyampaian materi pembelajaran secara online agar bisa diakses kapan pun dan dimana pun Turban et al. (2018). Adanya e-learning memberikan kemudahan dan fleksibilitas bagi pengajar atau peserta didik untuk memperoleh atau menyebarluaskan materi secara digital (Tetteh, 2016).

Dalam pengimplementasian e-learning, ada beberapa kelebihan dan kekurangan. Interaktivitas, kecepatan, visualisasi serta fleksibilitas melalui keunggulan media merupakan manfaat yang dapat diperoleh dari penggunaan e-learning (Sujana \& Yulia, 2005). Selain itu terdapat pula kekurangan $e$ learning seperti kurangnya pengetahuan juga skill untuk mengoperasikan internet (Rusman \& Riyana, 2011).

Beralihnya sistem pembelajaran online karena efek penyebaran Covid-19 menyebabkan terjadinya peningkatan intensitas pada pengguna e-learning, sehingga perlu dilakukan penelitian yang bertujuan untuk mengukur behaviour intention to use dan use behaviour pada penggunanya. Beberapa variabel yang dapat digunakan untuk mengukur dua variabel diatas seperti performance expectancy, effort expectancy, social influence, work life quality dan hedonic motivation.

Venkatesh, dkk. (2003), telah mengembangkan suatu model penelitian yaitu UTAUT (Unified Theory of Acceptance and Use of Technology) yang berfungsi untuk mengukur niat dan perilaku pengguna serta faktor-faktor tertentu. UTAUT dibangun dari 4 konstruksi berupa performance expectancy, effort expectancy, social expectancy dan facilities conditions dengan gender, age, voluntariness of use dan experience sebagai variabel moderator, yang kemudian pada tahun 2012 dikembangkan dengan menambahkan 3 variabel baru yaitu hedonic motivation, price value dan habit.

Manaf \& Ariyanti (2017) menunjukkan adanya signifikansi yang tidak terlalu besar antara Performance expectancy terhadap behavioural intention. Megadewandanu (2016) menunjukkan bahwa effort expectancy berpengaruh positif sebesar $11,1 \%$ terhadap behavioural intention to use. Indrawati \& Putri (2018) membuktikan bahwa behavioural intention dipengaruhi oleh social influence. Manaf \& Ariyanti (2017) menunjukkan bahwa 7,72\% behaviour intention to use dipengaruhi oleh hedonic motivation.

Samsudeen \& Mohamed (2019) mengemukakan Work life quality ialah ketika individu percaya jika dengan adanya sistem bisa meningkatkan kualitas dalam belajar individu tersebut. Sebuah penelitian yang dilakukan oleh Jaya, dkk. (2017) yang menguji hubungan antara variabel harapan kinerja, harapan kerja, pengaruh sosial dan kondisi fasilitasi terhadap niat perilaku yang mempengaruhi perilaku pengguna, menemukan bahwa semua variabel berpengaruh signifikan pada niat perilaku dan fasilitas terbukti mempengaruhi perilaku pengguna.

Penelitian ini bertujuan untuk menguji secara empiris pengaruh performance expectancy, effort expectancy, social influence, work-life quality, hedonic motivation terhadap behaviour intention to use dan behaviour intention to use terhadap use behaviour.

\section{Landasan Teori}

Theory of Acceptance and Use of Technology (UTAUT) merupakan suatu model acceptance of technology yang pertama kali dikembangkan oleh Venkatesh, dkk. (2003). Teori ini merupakan penggabungan delapan teori terkemuka seperti theory of reasoned action, technology acceptance model, motivational model, theory of planned behaviour, combined TAM and TPB, model of PC utilization, innovation diffusion theory, dan social cognitive theory yang bertujuan mengukur tingkat keberhasilan penerimaan penggunaan sistem atau teknologi kini. Dalam mengukur keberhasilan tingkat penerimaan sistem, UTAUT memakai variabel performance expectancy, effort expectancy, social influence, dan facilitating conditions terhadap behaviour intention to use. Sedangkan facilitating condition dan behaviour intention use menentukan penggunaan pada sistem atau teknologi (use behaviour).

Kemudian ditahun 2012, teori ini dikembangkan kembali dengan menambah tiga konstruksi variabel baru lainnya yaitu hedonic motivation, habit, price value. Model UTAUT2 terbukti dapat mengukur niat peggunaan dan penerimaan teknologi lebih baik dibandingkan dengan model ditahun 2003. Hal ini dibuktikan dengan membandingkan model penelitian sebelumnya bahwa variasi variabel pada niat perilaku UTAUT sebesar $56 \%$, sedangkan pada UTAUT2 meningkat menjadi 74\%, kemudian ditinjau dari nilai varian penggunaan teknologi pada UTAUT sebesar $40 \%$ yang meningkat menjadi $52 \%$ pada model UTAUT2.

Performance expectancy (ekspektasi kinerja) merupakan sejauh mana kepercayaan individu terhadap pemakaian sistem dapat menolong pengguna dalam peningkatan kinerja (Venkatesh, dkk. 2003). Penelitian sebelumnya oleh Samsudeen \& Mohamed (2019) menunjukkan bahwa PE memiliki pengaruh positif terhadap BI. Pada kali ini, peneliti memakai PE untuk mengukur tingkat kepercayaan pengguna sistem e-learning yang diterapkan dapat meningkatkan kinerja belajar 
mereka. Berdasarkan literatur diatas, terlihat bahwa PE memiliki signifikansi terhadap niat pengguna.

Pada penelitian yang dilakukan oleh Venkatesh, dkk. (2003) menunjukkan bahwa variable effort expectancy memiliki pengaruh yang besar terhadap niat pengguna dalam memakai sistem e-learning. Pada penelitian ini mengasumsikan jika sistem $e$ learning mudah digunakan, pengguna cenderung memakai sistem tersebut. Berdasarkan literatur diatas, terlihat bahwa PE memiliki signifikansi terhadap niat pengguna.

Khechine, dkk. (2020) mengungkapkan bahwa ada pengaruh positif antara SI dengan sistem pembelajaran sosial (e-learning). Dalam konteks penelitian ini, SI mengacu pada tekanan eksternal (seperti tekanan, dorongan dan pendapat dari kelurga, rekan, dan pihak eksternal lainnya) yang dapat mempengaruhi persepsi pengguna sehingga menimbulkan niat untuk memakai e-learning.

Penelitian Samsudeen \& Mohamed (2019) mengungkapkan bahwa terdapat hubungan positif anatara WLQ dengan niat pengguna e-learning. Dalam penelitian ini mengacu pada penggunaan $e$ learning dapat meningkatkan kualitas hidup penggunanya.

Penelitian yang telah dilakukan oleh Samsudeen \& Mohamed (2019) mengungkapkan bahwa terdapat pengaruh positif antara HM dengan niat pengguna $e$ learning. Dalam penelitian ini, mengacu kepada sejauh mana tingkat kesenangan pengguna karena adanya motivasi dalam e-learning dapat mempengaruhi niat pengguna e-learning.

Manaf \& Ariyanti (2017) dalam penelitiannya mengungkapkan bahwa $31.01 \%$ use behaviour dipengaruhi oleh behavioural intention. Pada penelitian ini mengacu sejauh mana niat pengguna dapat berpengaruh terhadap perilaku pengguna dalam memakai sistem e-learning .

\section{Metodologi Penelitian}

Penelitian ini dilakukan dengan memakai pendekatan kuantitatif. Responden dalam penelitian ini adalah mahasiswa Jurusan Manajemen Bisnis Politeknik Negeri Batam.

Kuesioner yang digunakan merupakan kuisioner yang diadaptasi dari (Venkatesh, dkk. (2012) dan Samsudeen \& Mohamed (2019) yang terdiri dari 25 item pertanyaan dengan skala numerik 4 poin yang disebar secara online melalui google form.

Pada penelitian ini memakai teknik analis data dengan alat analisis Partial Least Square (PLS) dengan software SmartPLS V3.0. Analisis data pada penelitian ini dilakukan dengan melakukan pengujian terhadap instrumen dan hipotesis. Uji instrument dilakukan melalui uji validitas konvergen dan uji validitas diskriminan kemudian dilakukan uji relibilitas.

Validitas Konvergen diukur melalui faktor loading yang memiliki nilai signifikansi $>0,70$ dan probabilitas indikator dapat dikatakan konvergen apabila Average Variance Extracted (AVE) pada masing-masing konstruksi memiliki nilai $>0,50$ (Hartono, 2014)

Validitas diskriminan diukur dengan melihat hasil nilai cross loading pada masing-masing indikator pertanyaan variable. Sedangkan pada uji reliabilitas konstruk diukur melalui dua pengukur internal yaitu Alpha Cronbach dan composite realibility dengan nilai > 0,70 (Ghozali \& Latan, 2015).

\section{Hasil Penelitian}

\section{Evaluasi Model dengan Outer Model}

Dalam penelitian ini, Indikator validitas konvergen yang digunakan adalah AVE > 0,50. Hasil perhitungan AVE terhadap Variabel dapat dilihat pada tabel 1 .

TABLE I

AVERAGE VARIANCE EXTRACTED (AVE)

\begin{tabular}{|c|c|}
\hline Variabel & $\begin{array}{c}\text { Average Variance } \\
\text { Extracted (AVE) }\end{array}$ \\
\hline PE & 0,669 \\
\hline EE & 0,697 \\
\hline SI & 0,572 \\
\hline WLQ & 0,646 \\
\hline HM & 0,914 \\
\hline BI & 0,734 \\
\hline UB & 0,880 \\
\hline
\end{tabular}

Sumber: data diolah (2021)

Dilihat dari tabel 1, masing-masing variable memiliki nilai AVE >0,50. Artinya probabilitas indikator tersebut telah memenuhi syarat validitas yang baik. Setelah uji konvergen terpenuhi dan valid, maka pengujian selanjutnya uji diskriminan dapat dilakukan. Evaluasi validitas diskriminan yaitu indikator-indikator di suatu konstruk seharusnya tidak saling berkolerasi dengan indikator di konstruk yang lain.

Berikut hasil pengujian diskriminan dengan Smart PLS versi 3.0 
TABLE 2

UJI DISKRIMINAN

\begin{tabular}{|c|c|c|c|c|c|c|c|}
\hline & BI & EE & HM & PE & SI & UB & WLQ \\
\hline BI1 & 0,920 & 0,585 & 0,759 & 0,779 & 0,532 & 0,653 & 0,616 \\
\hline BI2 & 0,920 & 0,576 & 0,805 & 0,748 & 0,538 & 0,660 & 0,591 \\
\hline BI3 & 0,920 & 0,693 & 0,734 & 0,684 & 0,647 & 0,718 & 0,668 \\
\hline BI4 & 0,631 & 0,449 & 0,486 & 0,440 & 0,345 & 0,362 & 0,363 \\
\hline EE1 & 0,594 & 0,656 & 0,544 & 0,514 & 0,376 & 0,545 & 0,468 \\
\hline EE2 & 0,530 & 0,873 & 0,393 & 0,446 & 0,533 & 0,511 & 0,519 \\
\hline EE3 & 0,501 & 0,881 & 0,430 & 0,496 & 0,585 & 0,482 & 0,537 \\
\hline EE4 & 0,600 & 0,906 & 0,521 & 0,604 & 0,597 & 0,528 & 0,627 \\
\hline HM1 & 0,783 & 0,518 & 0,966 & 0,783 & 0,571 & 0,631 & 0,625 \\
\hline HM2 & 0,775 & 0,556 & 0,928 & 0,684 & 0,528 & 0,644 & 0,600 \\
\hline HM3 & 0,808 & 0,579 & 0,973 & 0,789 & 0,598 & 0,659 & 0,650 \\
\hline PE1 & 0,645 & 0,598 & 0,675 & 0,792 & 0,538 & 0,480 & 0,587 \\
\hline PE2 & 0,726 & 0,677 & 0,633 & 0,859 & 0,553 & 0,525 & 0,530 \\
\hline PE3 & 0,599 & 0,331 & 0,668 & 0,838 & 0,392 & 0,412 & 0,427 \\
\hline PE4 & 0,626 & 0,390 & 0,667 & 0,863 & 0,458 & 0,396 & 0,444 \\
\hline PE5 & 0,612 & 0,534 & 0,577 & 0,732 & 0,454 & 0,387 & 0,435 \\
\hline SI1 & 0,485 & 0,329 & 0,518 & 0,486 & 0,714 & 0,530 & 0,453 \\
\hline SI2 & 0,465 & 0,409 & 0,591 & 0,553 & 0,792 & 0,394 & 0,401 \\
\hline SI3 & 0,427 & 0,587 & 0,335 & 0,362 & 0,691 & 0,317 & 0,463 \\
\hline SI4 & 0,473 & 0,591 & 0,336 & 0,375 & 0,820 & 0,436 & 0,455 \\
\hline UB1 & 0,669 & 0,594 & 0,647 & 0,529 & 0,555 & 0,937 & 0,504 \\
\hline UB2 & 0,676 & 0,583 & 0,618 & 0,488 & 0,495 & 0,939 & 0,613 \\
\hline WLQ1 & 0,649 & 0,492 & 0,624 & 0,592 & 0,497 & 0,559 & 0,845 \\
\hline WLQ2 & 0,414 & 0,477 & 0,356 & 0,323 & 0,443 & 0,381 & 0,770 \\
\hline WLQ3 & 0,503 & 0,615 & 0,550 & 0,471 & 0,471 & 0,466 & 0,795 \\
\hline S6E & $010195201)$ & & & & \\
\hline
\end{tabular}

Sumber: data diolah (2021)

Berdasarkan hasil pengolahan yang disajikan pada tabel 2 menampilkan bahwa nilai korelasi indikator terhadap konstruknya ada yang lebih lebih kecil dibandingkan nilai cross loading-nya seperti yang terlihat pada konstruk BI4, EE1 dan PE5.

Setelah BI4, EE1 dan PE5 dikeluarkan, maka dilakukanlah pengujian ulang terhadap model. Dari pengujian ulang, didapatkan nilai outer loading yang berbeda. Hasil pengujian ulang bisa diketahui pada tabel 3 .

TABLE 3

UJI DISKRIMINAN SETELAH INDIKATOR BI4, EE1 DAN PE5 DIKELUARKAN

\begin{tabular}{|c|c|c|c|c|c|c|c|}
\hline & BI & EE & HM & PE & SI & UB & WLQ \\
\hline BI1 & 0,939 & 0,503 & 0,759 & 0,761 & 0,533 & 0,652 & 0,616 \\
\hline BI2 & 0,939 & 0,505 & 0,805 & 0,733 & 0,538 & 0,660 & 0,592 \\
\hline BI3 & 0,921 & 0,609 & 0,734 & 0,667 & 0,647 & 0,718 & 0,667 \\
\hline EE2 & 0,530 & 0,906 & 0,394 & 0,435 & 0,529 & 0,511 & 0,518 \\
\hline EE3 & 0,485 & 0,922 & 0,430 & 0,465 & 0,582 & 0,482 & 0,534 \\
\hline EE4 & 0,587 & 0,955 & 0,521 & 0,582 & 0,594 & 0,528 & 0,623 \\
\hline HM1 & 0,776 & 0,436 & 0,966 & 0,773 & 0,572 & 0,631 & 0,620 \\
\hline HM2 & 0,781 & 0,461 & 0,929 & 0,677 & 0,530 & 0,644 & 0,599 \\
\hline HM3 & 0,798 & 0,495 & 0,972 & 0,765 & 0,599 & 0,659 & 0,645 \\
\hline PE1 & 0,643 & 0,601 & 0,675 & 0,822 & 0,538 & 0,480 & 0,585 \\
\hline PE2 & 0,737 & 0,608 & 0,633 & 0,853 & 0,553 & 0,525 & 0,529 \\
\hline PE3 & 0,608 & 0,248 & 0,667 & 0,850 & 0,395 & 0,412 & 0,422 \\
\hline PE4 & 0,634 & 0,338 & 0,667 & 0,891 & 0,459 & 0,396 & 0,443 \\
\hline SI1 & 0,495 & 0,282 & 0,518 & 0,478 & 0,721 & 0,530 & 0,455 \\
\hline SI2 & 0,469 & 0,373 & 0,591 & 0,535 & 0,796 & 0,394 & 0,402 \\
\hline SI3 & 0,411 & 0,622 & 0,335 & 0,346 & 0,682 & 0,317 & 0,459 \\
\hline SI4 & 0,476 & 0,603 & 0,336 & 0,365 & 0,816 & 0,436 & 0,455 \\
\hline & & & & & & & \\
\hline
\end{tabular}

\begin{tabular}{|c|c|c|c|c|c|c|c|}
\hline & BI & EE & HM & PE & SI & UB & WLQ \\
\hline UB1 & 0,674 & 0,549 & 0,647 & 0,539 & 0,556 & 0,937 & 0,502 \\
\hline UB2 & 0,688 & 0,479 & 0,618 & 0,465 & 0,496 & 0,939 & 0,612 \\
\hline WLQ1 & 0,655 & 0,413 & 0,624 & 0,578 & 0,499 & 0,559 & 0,846 \\
\hline WLQ2 & 0,445 & 0,474 & 0,356 & 0,328 & 0,442 & 0,381 & 0,781 \\
\hline WLQ3 & 0,477 & 0,606 & 0,549 & 0,457 & 0,468 & 0,466 & 0,784
\end{tabular}

Berdasarkan hasil pengolahan yang terdapat pada tabel 3 diatas menunjukan bahwa variabel telah memiliki diskriminant validity yang baik dan dapat dilanjutkan pada pengujian berikutnya yaitu uji hipotesis. Dikeluarkannya indiator BI4, EE1 dan akan mempengaruhi pada nilai AVE sebelumnya indikator BI4, EE1 dan PE5 masih ada dalam variabel masing-masing. Sehingga perlu dilakukan pengujian ulang tanpa indikator BI4, EE1 dan PE5 dalam masing-masing variable.

TABLE 4

AVERAGE VARIANCE EXTRACTED (AVE) TANPA INDIKATOR BI4, EE1 DAN PE5

\begin{tabular}{|c|c|c|}
\hline Variabel & $\begin{array}{c}\text { Average } \\
\text { Variance } \\
\text { Extracted } \\
\text { (AVE) } \\
\text { Lama }\end{array}$ & $\begin{array}{c}\text { Average } \\
\text { Variance } \\
\text { Extracted } \\
\text { (AVE) } \\
\text { Baru }\end{array}$ \\
\hline PE & 0,730 & 0,669 \\
\hline EE & 0,861 & 0,697 \\
\hline SI & 0,571 & 0,572 \\
\hline WLQ & 0,647 & 0,646 \\
\hline HM & 0,914 & 0,914 \\
\hline BI & 0,870 & 0,734 \\
\hline UB & 0,880 & 0,880 \\
\hline
\end{tabular}

Sumber: data diolah (2021)

Dari hasil pengujian ulang bisa terlihat bahwa ada perbedaan nilai AVE untuk variabel yang indikatornya telah dikeluarkan karena memiliki nilai cross loading yang lebih rendah, namun secara keseluruhan nilai AVE pada masing-varabel < 0,5.

Uji reliabilitas digunakan untuk melihat apakah tanggapan responden terhadap pertanyaan yang diberikan stabil atau konsisten. Uji reliabilitas konstruk diukur melalui dua pengukur internal yaitu Alpha Cronbach dan composite realibility dengan nilai > 0,7 (Ghozali \& Latan, 2015). 
TABLE 5

UJI REALIBILITAS

\begin{tabular}{|c|c|c|}
\hline Variabel & $\begin{array}{c}\text { Cronbach's } \\
\text { Alpha }\end{array}$ & $\begin{array}{c}\text { Composite } \\
\text { Reliability }\end{array}$ \\
\hline PE & 0,876 & 0,915 \\
\hline EE & 0,919 & 0,949 \\
\hline SI & 0,748 & 0,841 \\
\hline WLQ & 0,732 & 0,846 \\
\hline HM & 0,953 & 0,969 \\
\hline BI & 0,925 & 0,953 \\
\hline UB & 0,864 & 0,936 \\
\hline
\end{tabular}

Sumber: data diolah (2021)

Hasil pengujian realibilitas membuktikan nilai cronbach's alpha dan composite reability $>0,70$ sehingga bisa diterik kesimpulan jika keseluruhan variabel sudah reliabel.

\section{Evaluasi Model Struktural PLS-SEM}

Evaluasi model dengan model struktural dilakukan dengan tujuan agar bisa mengetahui besaran variabel independen bisa berpengaruh terhadap variabel dependen. Model struktural dapat diihat pada gambar 1 ini:

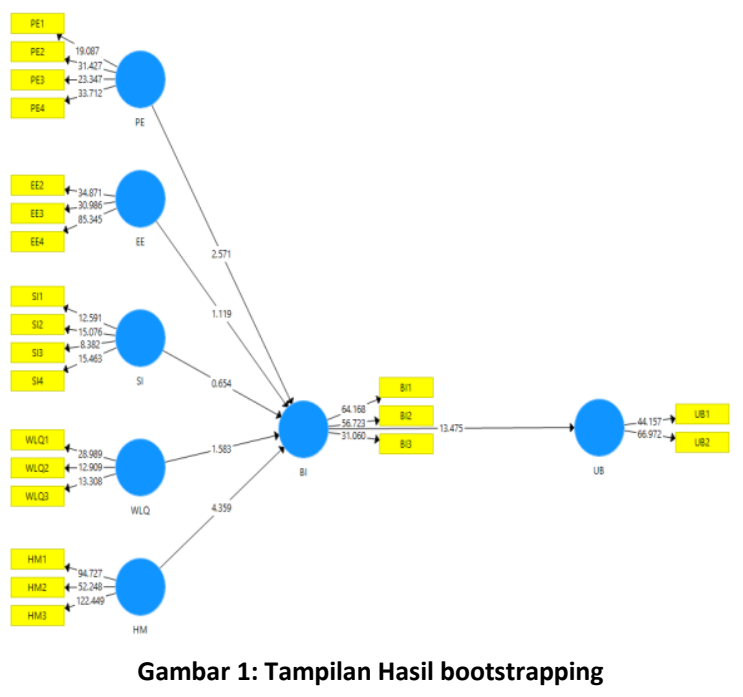

Coefficient determination ( $R$-Square) dipakai untuk mengukur banyaknya variabel endogen yang dipengaruhi oleh variabel lainnya. Nilai $\mathrm{R}^{2}$ disajikan dalam tabel 7.4 berikut:

TABLE 6

R SQUARE

\begin{tabular}{|c|c|}
\hline & $\boldsymbol{R}$ Square \\
\hline BI & 0,754 \\
\hline UB & 0,527 \\
\hline
\end{tabular}

Sumber: data diolah (2021)
Merujuk tabel 6, bisa diketahui jika nilai $\mathrm{R}^{2}$ pada variabel $\mathrm{BI}$ adalah 0,754 artinya variasi variabel yang terdiri PE, EE, SI, WLQ dan HM dapat menjelaskan variable BI dalam penelitian ini sebesar $75,4 \%$, sedangkan sisanya dijelaskan oleh variabel lainnya yang tidak ada pada model yang diajukan. Nilai R2 pada variabel UB sebesar 0,527 bermakna variasi variabel $\mathrm{BI}$ dapat menjelaskan variabel UB sebesar $52,7 \%$, dan sisanya dijelaskan oleh variabel lainnya yang tidak ada pada model yang diajukan.

Dalam mengukur signifikansi pada model prediksi pengujian model struktural, bisa terlihat dari nilai $t$ statistic antara variabel endogen dan variabel eksogen pada tabel Path Coefficient yang terdapat pada output SmartPLS dibawah ini.

TABLE 7

PATH COEFFICIENT

\begin{tabular}{|l|c|c|}
\hline & $\begin{array}{c}|c| \\
\text { Original } \\
\text { Sample }(\boldsymbol{O})\end{array}$ & $\begin{array}{c}\text { T- } \text { - Statistics } \\
(\boldsymbol{O} / \text { STERR })\end{array}$ \\
\hline PE -> BI & 0,256 & 2,571 \\
\hline EE -> BI & 0,109 & 1,119 \\
\hline SI -> BI & 0,058 & 0,654 \\
\hline WLQ -> BI & 0,126 & 1,583 \\
\hline HM -> BI & 0,455 & 4,359 \\
\hline BI-> UB & 0,726 & 13,475 \\
\hline
\end{tabular}

*Signifikansi 5\% (t-tabel 1.66)

Sumber: data diolah (2021)

Nilai pada Path Coefficient menunjukan tingkat signifikansi dalam pengujian hipotesis. Berdasarkan tabel 8.4 diketahui jika behaviour intention to use berpengaruh terhadap use behaviour to use dengan koefisien senilai 0,726 dan nilai t-hitung 13,475. Behaviour intention to use juga di pengaruhi oleh variabel hedonic motivation dengan koefisien senilai 0,455 dan nilai t-hitung 4,359 dan performance expectancy berpengaruh terhadap variabel behaviour intention to use dengan koefisien 0,058 dengan $\mathrm{t}$ hitung 2,571.

Ada 3 variabel yang tidak memiliki pengaruh terhadap behaviour intention to use yaitu effort expectancy, social influence dan work life quality karena nilai t-hitung <1,66 (tabel dengan signifikansi $5 \%)$.

\section{Pembahasan}

Hasil pengujian Performance expectancy terhadap variabel behaviour intention to use menghasilkan koefisien 0,058 dengan t-hitung 2,571. Hasil pengujian ini membuktikan bahwa ada pengaruh positif antara pengaruh performance expectancy terhadap behaviour intention to use. Hal ini membuktikan bahwa besarnya niat pengguna dalam memakai sistem e-learning dipengaruhi oleh 
variabel performance expectancy. Hasil penelitian ini konsisten dengan Penelitian dari Samsudeen \& Mohamed (2019), dimana responden menganggap bahwa penggunaan e-learning dapat membantu mereka untuk dapat meningkatkan kinerja/ prestasi mereka dalam belajar melalui kemudahan dan kecepatan dalam mengerjakan dan menyelesakan tugas-tugas kuliah, sehingga membuat niat dalam memakai sistem $e$-learning meningkat.

Hasil pengujian Effort expectancy (EE) terhadap behaviour intention to use (BI) mahasiswa dalam memakai sistem e-learning membuktikan koefisien $0,109<\mathrm{t}$-hitung yang menyiratkan bahwa effort expectancy tidak berpengaruh signifikan terhadap niat penggunaan dalam memakai e-learning. Pada penelitian ini diketahui bahwa EE adalah tingkat kemudahan yangdirasakan seorang individu terkait dengan penggunaan sistem (Venkatesh, dkk., 2003). Penelitian ini konsisten dengan hasil oleh Sutanto, dkk. (2018) menunjukkan tidak adanya pengaruh positif antara EE dengan BI. Hal ini disebabkan oleh persepsi mahasiswa yang lebih mementingkan kegunaan dalam pembelajaraan, mahasiswa tidak lagi menggap bahwa sistem e-learning yang digunakan oleh kampus merupakan sistem yang kompleks sehingga mudah untuk dipelajari, namun tidak berpengaruh terhadap intensitas mahasiswa dalam memakai sistem tersebut.

Hasil pengujian social influence (SI) terhadap behaviour intention to use (BI) mahasiswa dalam memakai sistem e-learning membuktikan bahwa tidak ada pengaruh positif. Hal ini membuktikan bahwa besarnya niat pengguna dalam memakai sistem e-learning tidak dipengaruhi oleh variabel social influence. Pada penelitian ini diketahui bahwa social influence merupakan sejauh mana seseorang percaya bahwa orang lain memiliki kemampuan untuk mempengaruhi orang lain untuk memakai sistem yang baru (Venkatesh, dkk., 2003). Penelitian oleh Raza, dkk. (2021) mengungkapkan bahwa social influence berpengaruh positif terhadap niat pengguna. Responden merasa bahwa lingkungan sosial disekitar seperti teman kerja, keluarga tidak mempengaruhi minat mereka dalam memakai sistem.

Hasil pengujian terhadap Work-life quality (WLQ) terhadap behaviour intention to use (BI) mahasiswa dalam memakai sistem e-learning membuktikan bahwa tidak ada pengaruh positif antara pengaruh work-life quality (WLQ) terhadap behaviour intention to use. Hal ini membuktikan bahwa besarnya niat pengguna dalam memakai sistem $e$ learning tidak dipengaruhi oleh variable work life quality. Tidak adanya pengaruh WLQ terhadap BI disebabkan masih banyaknya mahasiswa yang tidak merasakan atau mengalami perubahan yang signifikan terhadap kualitas hidup mereka ketika memakai e-learning .

Hasil pengujian Hedonic motivation (HM) terhadap behaviour intention to use (BI) mahasiswa dalam memakai sistem e-learning membuktikan bahwa ada pengaruh positif antara pengaruh hedonic motivation (HM) terhadap behaviour intention to use. Pada penelitian ini diketahui bahwa HM merupakan kesenangan yang didapat oleh pengguna dari suatu sistem atau teknologi (Venkatesh, dkk., 2012). Hal ini membuktikan bahwa besarnya niat pengguna dalam memakai sistem e-learning tidak dipengaruhi oleh hedonic motivation. Penelitian ini konsisten dengan penelitian Samsudeen \& Mohamad (2020) yang menunjukkan bahwa motivasi hedonis sebagai kesenangan yang berasal dari penggunaan teknologi mempengaruhi niat pengguna dalam memakai aplikasi e-learning.

Behaviour intention to use berpengaruh terhadap use behaviour to use dengan koefisien senilai 0,726 dan nilai t-hitung 13,475. Hasil pengujian membuktikan bahwa ada pengaruh positif antara pengaruh behaviour intention to use terhadap use behaviour. Hal ini membuktikan bahwa besarnya niat pengguna atau behaviour intention to use dipengaruhi oleh variabel use behaviour. Pada penelitian ini diketahui bahwa behaviour intention to use merupakan perilaku seseorang yang dapat dilihat dari besarnya intensitas niat penguna dalam memakai suatu sistem teknologi informasi. Seseorang memakai sistem, jika mereka percaya bahwa sistem tersebut berguna dalam membantu mereka penyelesaian pekerjaannya (Venkatesh, dkk., 2003). Hasil penelitian ini sesuai dengan penelitian yang dilakukan oleh Samsudeen \& Mohamed (2019) yang menunjukan bahwa keinginan/niat mahasiswa dalam memakai sistem mempengaruhi dan mendorong mereka untuk memakai e-learning dalam belajarnya.

\section{Kesimpulan}

Hasil penelitian membuktikan bahwa ada pengaruh positif antara pengaruh performance expectancy, hedonic motivation terhadap behaviour intention to use. Hasil penelitian juga menunjukkan bahwa tidak ada pengaruh positif antara effort expectancy terhadap behaviour intention to use dikarenakan mahasiswa mengaggap bahwa sistem e-learning yang diterapkan bukanlah sistem yang kompleks dan kemudahan akses pada e-learning tidak mempengaruhi niat mahasiswa untuk memakai sistem tersebut.

Selanjutnya social influence tidak memiliki pengaruh positif terhadap behaviour intention to use, hal ini dikarenakan penggunaan sistem e-learning bersifat wajib dan bukan sukarela dan pihak external tidak mempengaruhi niat mereka dalam memakai 
sistem tersebut. Work life quality terbukti tidak memiliki pengaruh positif terhadap behaviour intention to use, hal ini dikarenakan mahasiswa tidak mengganggap e-learning memberikan efisiensi untuk mendapatkan materi pembelajaran secara lebih bebas. Mahasiswa cenderung mencari materi tambahan dari sumber lainnya.

Selanjutnya hasil penelitian ditemukan bahwa behaviour intention to berpengaruh positif terhadap use behaviour mahasiswa. Keinginan/ niat mahasiswa dalam memakai sistem mempengaruhi dan mendorong mereka untuk memakai e-learning dalam belajarnya.

\section{Daftar Pustaka}

A. Ghozali, I., \& Latan, H. (2015). Partial least squares konsep, teknik dan aplikasi menggunakan program smartpls 3.0 untuk penelitian empiris. Semarang: Badan Penerbit UNDIP.

B. Hartono, J. (2014). Metodologi Penelitian Bisnis (Salah Kaprah dan Pengalamanpengalaman): BPFE.

C. Indrawati, I., \& Putri, D. (2018). Analyzing Factors Influencing Continuance Intention of E-Payment Adoption Using Modified UTAUT 2 Model.

D. Jaya, S. N., Anshari Nur, M. N., Faslih, A., \& Anshari Nur, M. N. (2017). Analysis of Behaviour of E-learning Users by Unified Teory of Acceptance and Use of Technology (UTAUT) Model A Case Study of Vocational Education in Halu Oleo University. Jurnal Vokasi Indonesia(Vol 5, No 2 (2017): July December). Retrieved from http://jvi.ui.ac.id/index.php/jvi/article/view/1 $\underline{09}$

E. Khechine, H., Raymond, B., \& Augier, M. (2020). The adoption of a social learning system: Intrinsic value in the UTAUT model. British Journal of Educational Technology, 51(6), 2306-2325. doi:https://doi.org/10.1111/bjet.12905

F. Manaf, N., \& Ariyanti, M. (2017). Exploring Key Factors on Technology Acceptance of Mobile Payment Users in Indonesia Using Modified UTAUT2 Model Use Case: ABC Easy Tap. International Journal of Management and Applied Science, 3(1), 40-44.

G. Megadewandanu, S. (2016). Exploring mobile wallet adoption in Indonesia using UTAUT2: An approach from consumer perspective. Paper presented at the 2016 2nd International
Conference on Science and TechnologyComputer (ICST).

H. Raza, S. A., Qazi, W., Khan, K. A., \& Salam, J. (2021). Social isolation and acceptance of the learning management system (LMS) in the time of COVID-19 pandemic: an expansion of the UTAUT model. Journal of Educational Computing Research, 59(2), 183-208.

I. Rosenberg, M. J. (2001). E-Learning: Strategies for Delivering Knowledge in the Digital Age: McGraw-Hill Education.

J. Rusman, D. K., \& Riyana, C. (2011). Pembelajaran berbasis teknologi informasi dan komunikasi. Bandung: Rajawali Pers.

K. Samsudeen, S. N., \& Mohamed, R. (2019). University students' intention to use elearning systems. Interactive Technology and Smart Education, 16(3), 219-238. doi:10.1108/ITSE-11-2018-0092

L. Sujana, J. G., \& Yulia, Y. (2005). Perkembangan Perpustakaan di Indonesia: IPB Press.

M. Sutanto, S., Ghozali, I., \& Handayani, R. S. (2018). Faktor-Faktor Yang Memengaruhi Penerimaan Dan Penggunaan Sistem Informasi Pengelolaan Keuangan Daerah (Sipkd) Dalam Perspektif the Unified Theory of Acceptance and Use of Technology 2 (Utaut 2) Di Kabupaten Semarang. Jurnal Akuntansi dan Auditing, 15(1), 37-68.

N. Tetteh, G. A. (2016). Effects of business school student's study time on the learning process. Journal of International Education in Business Vol. 9 No. 2, 1-18.

O. Turban, E., Outland, J., King, D., Lee, J. K., Liang, T. P., \& Turban, D. C. (2018). Electronic Commerce 2018: A Managerial and Social Networks Perspective: Springer International Publishing.

P. Venkatesh, V., Morris, M. G., Davis, G. B., \& Davis, F. D. (2003). User acceptance of information technology: Toward a unified view. MIS quarterly, 425-478.

Q. Venkatesh, V., Thong, J. Y., \& Xu, X. (2012). Consumer acceptance and use of information technology: extending the unified theory of acceptance and use of technology. MIS quarterly, 157-178. 